\title{
Cancer risks in painters: study based on the New Zealand Cancer Registry
}

\author{
Peter B Bethwaite, Neil Pearce, James Fraser
}

\begin{abstract}
Painters are exposed to a range of complex chemical mixtures which include organic solvents and dye products with known carcinogenic and mutagenic potential. Trade painters or those manufacturing paints and coatings have increased rates of non-malignant diseases and cancers; including lung cancer, acute leukaemia, bladder cancer, and cancers of the oesophagus, larynx, biliary system, liver, skin, and large bowel. A series of case-control studies of painters, based on the New Zealand Cancer Registry, are presented. These concerned 19904 male patients registered for the period 1980-4 who were aged 20 or older at the time of registration. For each cancer site studied, the registrants for all other cancer sites formed the control group. Three cancer sites were associated with work as a painternamely, bladder tumours (odds ratio (OR) $1 \cdot 52,95 \%$ confidence interval $(95 \%$ CI) $1.00-$ $2 \cdot 31$ ), kidney and other urothelial tumours (OR $1 \cdot 45,95 \%$ CI 0.85-2.50), and multiple myeloma (OR 1.95, 95\%, CI 1.05-3.65). Risks for multiple myeloma were greater among car or spray painters and signwriters (OR $2 \cdot 81$ ) compared with construction and general painters (OR 1.80). No increased risk was found for leukaemia or for respiratory, biliary, skin, or gastrointestinal cancers.
\end{abstract}

Persons engaged in the manufacture and application of paint are potentially exposed to a heterogeneous group of substances, in particular a wide range of organic solvents and dye products. Several studies have investigated the occupational risks of work in the painting trade or in industries manufacturing paint and coatings. Increased risks have been shown

Department of Community Health, Wellington School of Medicine, Wellington, New Zealand

P B Bethwaite, N Pearce

National Health Statistics Centre, Wellington, New Zealand

$\mathrm{J}$ Fraser to occur for lung cancer, ${ }^{1-5}$ acute leukaemia, ${ }^{267}$ multiple myeloma, ${ }^{8-11}$ bladder cancer, ${ }^{512-15}$ and cancers of the oesophagus, larynx, biliary system and liver, ${ }^{2516}$ skin, large bowel, and rectum. ${ }^{16}$ Also, increased rates of non-malignant liver disease, ${ }^{17}$ heart disease, ${ }^{5}$ and respiratory and upper gastrointestinal tract disease ${ }^{2}$ have been described, together with a form of chronic toxic encephalopathy known as "painters syndrome." ${ }^{518}$

We report here on the findings of a case-control study, based on the New Zealand Cancer Registry, undertaken to assess the risk of cancer for New Zealand men employed as painters and to generate hypotheses for further testing.

\section{Methods}

Our cohort comprised male patients who were registered with the New Zealand Cancer Registry for the period $1980-4$, who were aged 20 or older at registration. The New Zealand Cancer Registry is population based and collects data from public and private hospitals throughout the country, with further information obtained from death certificates and incidental necropsy findings. For the study period under consideration registration was virtually complete. ${ }^{19}$

Occupation is defined as the patients' current or most recent occupation at the time of registration, and is coded in the New Zealand Cancer Registry using the New Zealand Standard Classification of Occupations (NZSCO) ${ }^{20}$; this is a modification of the International Standard Classification of Occupations..$^{21}$ Of the total 24762 male registrants, occupational information was coded for 19904 $(80 \%)$ and data analysis was confined to these. Table 1 shows the distribution of cancers in this group.

The NZSCO identifies two groups of painters. The first group consists of general painters, painter decorators, and steel and other construction painters. The second group comprises car painters, spray painters, signwriters, and other unclassified painters. The classification does not allow for the identification of workers manufacturing paint and coatings.

The design consisted of a series of case-control studies using the overall group of 19904 registrants, to examine the association between diverse cancer sites and work as a painter. For each cancer site (see 
table 1) the registrants for the other cancer sites formed the control group. For example, in the analysis for cancers of the buccal cavity and pharynx (International Classification of Disease (ICD), 9th revision, codes $140-149^{22}$, the case group consisted of the 698 registrants with this type of cancer, and the other 19206 cancer registrants formed the control group (table 1). The identical procedure was then applied to the other diverse sites. The analysis was conducted using the Statistical Analysis System. ${ }^{23}$ Age adjusted odds ratios (ORs) were estimated by the Mantel-Haenszel method ${ }^{24}$ using 10 year age groups. Confidence intervals $(95 \% \mathrm{CI})$ were calculated using Miettinen's approximate method. ${ }^{25}$

Several previous case-control studies based on the New Zealand Cancer Registry have used "other cancers" to form the control group. The relevant issues in this design are described elsewhere. ${ }^{26}{ }^{27}$ The principle advantage of using other cancers as controls is the minimisation of information bias, together with a reduction in selection bias owing to incomplete cancer registration. A potential disadvantage is the possibility of selection bias if the exposure under consideration is associated with an increased risk for other cancer sites. Such bias is likely to be minimal in occupational studies, however, unless exposure is associated with a common cancer. ${ }^{26}$ Even in this situation the direction of bias is towards the null value. Generally this bias can be minimised by selective exclusion of exposure related cancers from the control group, although this may in certain situations actually lead to an increase in net bias. ${ }^{27}$

Table 1 Distribution of cancer cases, by site in New Zealand men aged 20 or older, 1980-4

\begin{tabular}{|c|c|c|c|}
\hline Site of cancer & $\begin{array}{l}I C D \\
\text { category }\end{array}$ & $\begin{array}{l}\text { No of cases with } \\
\text { occupation } \\
\text { recorded }(\%)\end{array}$ & $\begin{array}{l}\text { Total } \\
\text { cases }\end{array}$ \\
\hline $\begin{array}{l}\text { Buccal cavity } \\
\text { Oesophagus } \\
\text { Stomach } \\
\text { Colon } \\
\text { Rectum } \\
\text { Liver } \\
\text { Gallbladder } \\
\text { Pancreas } \\
\text { Nasal cavity, sinus } \\
\text { Larynx } \\
\text { Lung } \\
\text { Soft tissue sarcoma } \\
\text { Malignant melanoma } \\
\text { Prostate } \\
\text { Testis } \\
\text { Bladder } \\
\text { Kidney } \\
\text { Brain } \\
\text { Non-Hodgkin's lymphoma } \\
\text { Hodgkin's lymphoma } \\
\text { Multiple myeloma } \\
\text { Leukaemia } \\
\text { Other }\end{array}$ & $\begin{array}{l}140-149 \\
150 \\
151 \\
153 \\
154 \\
155 \\
156 \\
157 \\
160 \\
161 \\
162 \\
171 \\
172 \\
185 \\
186 \\
188 \\
189 \\
191 \\
200,202 \\
201 \\
203 \\
204-209 \\
-\end{array}$ & $\begin{array}{r}583(82) \\
385(83) \\
1014(81) \\
2043(82) \\
1376(82) \\
184(83) \\
120(87) \\
571(82) \\
46(79) \\
303(80) \\
4224(84) \\
142(83) \\
1116(77) \\
2435(73) \\
399(92) \\
912(72) \\
542(81) \\
431(90) \\
535(82) \\
170(91) \\
295(83) \\
534(82) \\
1544(78)\end{array}$ & $\begin{array}{r}708 \\
463 \\
1258 \\
2500 \\
1679 \\
223 \\
138 \\
695 \\
58 \\
379 \\
5031 \\
171 \\
1448 \\
3340 \\
435 \\
1259 \\
666 \\
481 \\
652 \\
186 \\
355 \\
649 \\
1988\end{array}$ \\
\hline Total & $140-209$ & $19904(80)$ & 24762 \\
\hline
\end{tabular}

\section{Results}

Table 2 shows the age adjusted ORs for the various cancer sites in New Zealand painters. The principal findings are the increased relative risk for urinary cancers and multiple myeloma. There was little evidence of an increased risk for other cancer sites; notably no excess risk occurred for lung, gastrointestinal, liver and bilary tumours, or leukaemia.

Table 3 shows that the excess risks pertain to both bladder (ICD, 9th revision, code 188) and to kidney and other urothelial tumours (ICD, 9th revision, code 189), although the number of cases is small in the 189 group. Risks for bladder and urinary tumours were slightly higher in the car, spray, and signwriter painter group (OR $=1.82,95 \%$ CI $0.85-2 \cdot 5)$ than among construction and general painters (OR = $1 \cdot 47,95 \%$ CI 1.02-2.13). A larger difference was found for multiple myeloma, with the car, spray, and signwriter group having a greater risk $(\mathrm{OR}=\mathbf{2} \cdot \mathbf{8 1}$, 95\% CI 0.73-10.7), than construction and general painters $(O R=1 \cdot 80,95 \%$ CI $0 \cdot 89-3 \cdot 64)$.

Table 4 shows that the ORs for both the urological cancers and for multiple myeloma were particularly increased in younger persons.

\section{Discussion}

The finding of an increased risk of bladder cancer among painters is consistent with previous studies. An excess of bladder tumours was noted in a proportionate mortality study of artistic painters. A historical cohort study conducted on 1916 Geneva trade painters, followed up from 1970 until 1984, showed a standardised mortality ratio (SMR) for painters of 206 (95\% CI 97-387) and a standardised incidence ratio of 171 (95\% CI 101-272) for bladder tumours. ${ }^{5}$ No increased risk was noted for kidney tumours in this study. Jensen et al in a case-control study undertaken in Copenhagen, found an increased risk for bladder cancer in trades undertaking painting $(\mathrm{OR}=1 \cdot 39,95 \% \mathrm{CI} 1 \cdot 04-1 \cdot 86)$ for 10 years duration of employment, with a significant trend for duration of employment. ${ }^{12}$ A German case-control study examining lifestyle and occupational risk factors for lower urinary tract cancer found an increased risk in spray painters $(\mathrm{OR}=4 \cdot 67,95 \% \mathrm{CI} 2 \cdot 10-10 \cdot 39){ }^{13}$ Olsen and Jensen, in an analysis of a linked data set from the Cancer Registry and the Danish Supplementary Pensions Fund found a significant increase in cancers of the lower urinary tract among persons employed in paint and glue manufacture and among persons working in paint shops. ${ }^{14}$ An increased risk of bladder cancer has also been described in painters in the United States. ${ }^{15}$

Increased risk of multiple myeloma has been associated with a number of accupational groups including farmers, ${ }^{28-30}$ wood workers, ${ }^{31} 32$ printers, ${ }^{33}$ workers in chemical manufacturing plants, ${ }^{34}$ and in 
Table 2 Age adjusted ORs (95\% CI) for cancer in painters; New Zealand Cancer Registry 1980-4

\begin{tabular}{|c|c|c|c|c|}
\hline Site of cancer & ICD category & Exposed cases & Exposed controls & $O R(95 \% C I)$ \\
\hline $\begin{array}{l}\text { Buccal cavity } \\
\text { Oesophagus } \\
\text { Stomach } \\
\text { Colon } \\
\text { Rectum } \\
\text { Liver } \\
\text { Gallbladder } \\
\text { Pancreas } \\
\text { Larynx } \\
\text { Lung } \\
\text { Soft tissue sarcoma } \\
\text { Malignant melanoma } \\
\text { Prostate } \\
\text { Testis } \\
\text { Urinary, bladder } \\
\text { Brain, nervous system } \\
\text { Non-Hodgkin's lymphoma } \\
\text { Hodgkin's lymphoma } \\
\text { Multiple myeloma } \\
\text { Leukaemia } \\
\text { Other }\end{array}$ & $\begin{array}{l}140-149 \\
150 \\
151 \\
153 \\
154 \\
155 \\
156 \\
157 \\
161 \\
162 \\
171 \\
172 \\
185 \\
186 \\
188,189 \\
191,192 \\
200,202 \\
201 \\
203 \\
204-209 \\
-\end{array}$ & $\begin{array}{r}10 \\
5 \\
19 \\
28 \\
25 \\
2 \\
3 \\
6 \\
6 \\
88 \\
1 \\
14 \\
43 \\
5 \\
38 \\
10 \\
9 \\
1 \\
10 \\
5 \\
37\end{array}$ & $\begin{array}{r}343 \\
380 \\
995 \\
2015 \\
1351 \\
353 \\
117 \\
565 \\
297 \\
265 \\
141 \\
1102 \\
2392 \\
394 \\
315 \\
345 \\
526 \\
169 \\
285 \\
348 \\
316\end{array}$ & $\begin{array}{l}0.78(0.41-1.47) \\
0.70(0.29-1.71) \\
1.04(0.65-1.67) \\
0.74(0.50-1.09) \\
0.99(0.66-1.50) \\
0.61(0.15-2.41) \\
1.41(0.45-4.44) \\
0.57(0.26-1.27) \\
1.06(0.47-2.41) \\
1.12(0.93-1.52) \\
0.43(0.06-2.88) \\
0.73(0.43-1.25) \\
1.02(0.73-1.41) \\
0.99(0.37-2.66) \\
1.53(1.10-2.14) \\
1.29(0.68-2.46) \\
0.97(0.50-1.90) \\
0.38(0.06-2.54) \\
1.95(1.05-3.65) \\
0.54(0.23-1.30) \\
1.03(0.73-1.45)\end{array}$ \\
\hline
\end{tabular}

Table 3 Age adjusted ORs (95\% CI) for painters by subsite; New Zealand Cancer Registry 1980-4

\begin{tabular}{lllll}
\hline Subsite & $\begin{array}{l}\text { ICD } \\
\text { category }\end{array}$ & $\begin{array}{l}\text { Exposed } \\
\text { cases }\end{array}$ & $\begin{array}{l}\text { Exposed } \\
\text { controls }\end{array}$ & OR $(95 \%$ CI $)$ \\
\hline Bladder & 188 & 24 & 888 & $1 \cdot 52(1 \cdot 00-2 \cdot 31)$ \\
Kidney & 189 & 14 & 528 & $1 \cdot 45(0 \cdot 85-2 \cdot 50)$ \\
\hline
\end{tabular}

workers exposed to petroleum products. ${ }^{35}$ Several case-control studies have reported small non-significant excess risks of multiple myeloma among painters. ${ }^{91011}$ A cohort study based on Swedish death certificates of 416 paint industry workers was undertaken by Lundberg and colleagues. Among 96 workers who died, three deaths occurred from multiple myeloma against 0.6 deaths expected. ${ }^{8}$ Our study found no excess risk for leukaemia among painters, although this has been reported by other workers; a study based on New Zealand death certificates found an increased risk for all leukaemias in male painters (SMR 234, 95\% CI 101-461), ${ }^{7}$ as did a Swedish casecontrol study where painters with exposure to occupational organic solvents exhibited an OR of 13 $\left(95 \%\right.$ CI 2-554). ${ }^{6}$

The exposure of painters to chemical compounds is complex and the composition of paints and glues is likely to vary between countries. No specific study has been undertaken in New Zealand to document the various exposures among different groups of painters. Painters are exposed to various dye and pigment products, with one of the most common exposures being to organic solvents. ${ }^{616}{ }^{17}$ Painters are exposed to organic solvents either as vapours or by direct skin application through the regular use of cleaning solvents. A common solvent used by house painters is white spirit (Stoddard's solvent), which is a mixture of around $20 \%$ aromatic and $80 \%$ aliphatic hydrocarbons. Paints and lacquers also contain a mixture of aromatic solvents $\left(\mathrm{C}_{9}-\mathrm{C}_{10}\right)$, toluene, and xylenes. Spray painters are also exposed to aerosols of paints, fillers, and catalysts. ${ }^{176}$ Also, some painters use a range of adhesive and degreasing agents that are heterogeneous solvent products commonly containing trichloroethylene, $\mathrm{n}$-hexane, and methylethyl ketone. ${ }^{36}{ }^{37}$ The use of benzene is prohibited as a pure solvent in most countries, but may be present in small quantities as an impurity in other solvents. ${ }^{6} \mathrm{~A}$ range of organic solvents has been shown to have mutagenic properties but detailed knowledge on the specific risks posed by individual solvents is limited. ${ }^{38-40}$

Also, exposure to organic solvents has been linked to a number of haematopoietic malignancies, in particular, lymphomas, leukaemia, and multiple myeloma. ${ }^{641-45}$

Table 4 Age adjusted ORs (95\% CI) for cancer in painters by age group; New Zealand Cancer Registry 1980-4

\begin{tabular}{|c|c|c|c|c|}
\hline \multirow[b]{3}{*}{ Site (ICD) } & \multicolumn{4}{|c|}{ Age group (y) } \\
\hline & \multicolumn{2}{|l|}{$20-59$} & \multicolumn{2}{|l|}{$\geqslant 60$} \\
\hline & Exposed & $O R(95 \% C I)$ & Exposed & $O R(95 \% C I)$ \\
\hline $\begin{array}{l}\text { Bladder (188) } \\
\text { Kidney (189) } \\
\text { Multiple myeloma (203) }\end{array}$ & $\begin{array}{l}9 \\
7 \\
5\end{array}$ & $\begin{array}{l}2.27(1.15-4.48) \\
1.94(0.91-4.19) \\
4.23(1.80-9.91)\end{array}$ & $\begin{array}{r}15 \\
7 \\
5\end{array}$ & $\begin{array}{l}1.27(0.75-2 \cdot 15) \\
1.16(0.54-2 \cdot 48) \\
1.27(0.52-3 \cdot 10)\end{array}$ \\
\hline
\end{tabular}


The interpretation of finding a greater risk for urological cancers and multiple myeloma in younger male painters is uncertain. This may reflect a change over time in the composition of paints and glue products, together with a change in the work practices of painters or in other environmental confounding factors. Alternatively mortality among younger painters may reduce those at risk of developing cancer at an older age. Further, the difference may be a function of the use of a relative measure of effect rather than an absolute measure. ${ }^{46}$

Two main limitations of a registry based study of this type are the lack of valid information on exposure and the lack of information on potential confounding factors such as cigarette smoking. Knowledge of only the most recent occupation of registrants provides a crude occupational history, with no information on specific exposures. Secondary information on smoking behaviour is available from the 1981 census of population and dwellings, which showed that $46 \%$ of New Zealand male painters were regular cigarette smokers, compared with $38 \%$ of the total male workforce. ${ }^{47}$ The higher proportion of smoking behaviour among male painters may partially explain the excess of bladder cancer seen in this group. It is noteworthy, however, that no other cancer sites strongly associated with cigarette smoking showed an excess of cases among painters. Siemiatycki et al have assessed the degree of confounding bias related to smoking and socioeconomic state in estimates of occupational associations with bladder cancer. They concluded that relative risks in excess of 1.20 were unlikely to be attributable to confounding bias by these variables ${ }^{48}$ Whether it is prudent to generalise from these results is uncertain, although similar results were reported from Finnish ${ }^{49}$ and American ${ }^{50}$ studies.

In summary, this cancer registry based case control study has examined the cancer experience of male painters, who are known from previous work to have an excess of certain cancer types. Painters are exposed to a wide range of complex mixtures that include a number of known carcinogenic and. mutagenic chemicals including organic solvents and dye products. The findings are consistent with previous work showing an increased risk for urological and haematic cancers among painters. The study found an excess of cases of multiple myeloma, however, among painters whereas other workers found an excess of leukaemia. These associations point to priorities for further research into the occupational exposures and cancer experience of New Zealand painters.

Peter Bethwaite is supported by the Medical Research Council of New Zealand under a Training Fellowship in epidemiology. James Fraser thanks the
Director General of Health for permission to publish the data.

Requests for reprints to: Peter B Bethwaite MB, Department of Community Health, Wellington School of Medicine, PO Box 7643, Wellington, New Zealand.

1 Stockwell HG, Matanoski GM. A case-control study of lung cancer in painters. J Occup Med 1985;27:125-6.

2 Englund A. Cancer incidence among painters and some allied trades. J Toxicol Environ Health 1980;6:1267-73.

3 Dubrow R, Wegman DH. Cancer and occupation in Massachusetts: a death certificate study. Am J Ind Med 1984;6: 207-30.

4 Menck HR. Henderson BE. Occupational differences in rates of lung cancer. J Occup Med 1976;18:797-801.

5 Guberan E, Usel M, Raymond L, Tissot R, Sweetnam PM. Disability, mortality and incidence of cancer among Geneva painters and electricians: an historical prospective study. $\mathrm{Br} J$ Ind Med 1989;46:16-23.

6 Lindquist R, Nilsson B, Eklund G, Gahrton G. Increased risk of developing acute leukemia after employment as a painter. Cancer 1987;60:1378-84.

7 Pearce N, Howard JK. Occupation, social class and male cancer mortality in New Zealand 1974-78. Int J Epidemiol 1986; 15:456-62.

8 Lundberg I. Mortality and cancer incidence among Swedish paint industry workers with long term exposure to organic solvents. Scand J Work Environ Health 1986;12:108-113.

9 Cuzick J, De Stavola B. Multiple myeloma- a case-control study. Br J Cancer 1988;57:516-20.

10 Friedman GD. Multiple myeloma: relation to propoxyphene and other drugs, radiation and occupation. Int $J$ Epidemiol 1986;15:424-6.

11 Adelstein AM. Occupational mortality: cancer. Ann Occup Hyg 1972;15:53-7.

12 Jensen OM, Wahrendorf J, Knudsen JB, Sorensen BL. The Copenhagen case-referent study on bladder cancer: risks among drivers, painters and certain other occupations. Scand $J$ Work Environ Health 1987;13:129-34.

13 Claude J, Kunze E, Frentzel-Beyme R, Paczkowski IC, Schnieder J, Schubert H. Life-style and occupational risk factors in cancer of the lower urinary tract. Am J Epidemiol 1986;124:578-89.

14 Olsen JH, Jensen OM. Occupation and cancer risk in Denmark: an analysis of 93,810 cancer cases $1970-79$. Scand $J$ Work Environ Health 1987;13 (suppl 1):1-91.

15 Wynder EL, Onderdonk J, Mantel N. an epidemiological investigation of cancer of the bladder. Cancer 1963;16: 1388-1407.

16 Morgan RW, Kaplan SD, Gaffey WR. A general mortality study of production workers in the paint and coatings manufacturing industry. $J$ Occup Med 1981;23:13-21.

17 Dossing M, Arlien-Soborg P, Petersen LM, Ranek L. Liver damage associated with occupational exposure to organic solvents in house painters. Eur J Clin Invest 1983;13:151-7.

18 Waldron HA. Solvents and the brain. Br J Ind Med 1986;43: 73-4.

19 Foster FH. The New Zealand Cancer Registry. New Zealand Medical Journal 1977;86:341-3.

20 Department of Statistics. New Zealand standard classification of occupations. Wellington: Department of Statistics, 1980.

21 International Labour Office. International Standard Classification of Occupations. Geneva: ILO, 1968.

22 World Health Organisation. Manual of the international statistical classification of diseases, injuries and causes of death. 9th revision. Geneva: WHO, 1977.

23 Statistical Analysis System. User's Guide. Statistics. Cary NC: SAS Institute, 1985

24 Mantel N, Haenszel W. Statistical aspects of the analysis of data from retrospective studies of disease. J Natl Cancer Inst 1959;22:719-48.

25 Miettinen OS. Estimation and estimability in case-control studies. Am J Epidemiol 1976;103:226-35.

26 Smith AH, Pearce NE, Callas PW. Cancer case-control studies with other cancers as controls. Int J Epidemiol 1988;17: 298-306.

27 Pearce NE, Checkoway HA. Case-control studies with other 
diseases as controls: problems of excluding exposure related diseases. Am J Epidemiol 1988;127:851-6.

28 Pearce NE, Smith AH, Howard JK, Sheppard RA, Giles HJ Teaque CA. Case-control study of multiple myeloma and farming. Br J Cancer 1986;54:493-500.

29 Gallagher RP, Spinelli JJ, Elwood JM, Skippen DH. Allergies and agricultural exposures as risk factors for multiple myeloma. Br J Cancer 1983;48:853-7.

30 Cantor KP, Blair A. Farming and mortality from multiple myeloma: a case-control study with use of death certificates. $J$ Natl Cancer Inst 1984;72:251-5.

31 Tollerud DJ, Brinton LA, Stone BJ, Tobacman JK, Blattner WA. Mortality from multiple myeloma among North Carolina furniture workers. J Natl Cancer Inst 1985;74:799-801.

32 Milham S. Occupational mortality in Washington State 1950 1971. Washington DC. US Government Printing Office, 1976. (DHEW Publ No 76.)

33 Greene MH, Hoover RN, Eck RL, Fraumeni JF. Cancer mortality among printing plant workers. Environ Res 1979; 20:66-73.

34 Blattner WA, Blair A, Mason TJ. Multiple myeloma in the US, 1950-1975. Cancer 1981;48:2547-54.

35 Linet MS, Harlow SD, McLaughlin JK. A case-control study of multiple myeloma in whites: chronic antigenic stimulation, occupation and drug use. Cancer Res 1987;47:2978-81.

36 Kumai M, Koizumi A, Saito $\mathrm{K}$, et al. A nationwide survey on organic solvent component in various solvent products: Part 2-Heterogenous products such as paints, inks and adhesives. Industrial Health 1983;21:185-97.

37 Inoue $\mathrm{T}$, Takeuchi $\mathrm{Y}$, Hisanga $\mathrm{N}$, et al. A nationwide survey on organic solvent component in various solvent products: Part 1 -Homogenous products such as thinners, degreasers and reagents. Industrial Health 1983;21:175-83.

38 Meretojn T, Jarventans H, Sossu M, Vainio H. Chromosome aberrations in lymphocytes of workers exposed to styrene. Scand J Work Environ Health 1978;2 (suppl):259-64.

39 Funes-Cravito F, Kolmodin-Hedman B, Lindsten J, Nordenskjold M. Chromosome aberrations and sister-chromatid exchanges in workers in chemical laboratories and a rotoprinting factory and in children of women laboratory workers. Lancet 1977; ii:322-5.

40 Forni A, Pacifico F, Limonta A. Chromosome studies in workers exposed to benzene or toluene or both. Arch Environ Health 1971;22:373-8.

41 Rinsky RA, Young RJ, Smith AB. Leukemia in benzene workers. Am J Ind Med 1981;2:217-45.

42 Checkoway $H$, Wilcosky $T$, Wolf $P$, Tyroler $H$. An evaluation of the associations of leukemia and rubber industry solvent exposures. Am J Ind Med 1984;5:239-49.

43 Olsson H, Brandt L. Occupational exposure to organic solvents and Hodgkin's disease in man. Scand $J$ Work Environ Health 1980;6:302-5.

44 Hardell L, Ericksson M, Lerner P, Lundgren E. Malignant lymphoma and exposure to chemicals, especially organic solvents, chlorophenols and phenoxyacids: A case-control study. Br J Cancer 1981;42:169-76.

45 Rinsky RA, Smith AB, Hornung R, et al. Benzene and leukemia: an epidemiological risk assessment. $N$ Engl J Med 1987; 316:1044-50.

46 Rothman KJ. Modern epidemiology. Boston: Little Brown and Co, 1986.

47 Department of Statistics. New Zealand Census of Population and Dwellings 1981: Bulletin on cigarette smoking. Wellington: Department of Statistics, 1983.

48 Siemiatycki J, Wacholder S, Dewar R, Cardis E, Greenwood C Richardson $\mathrm{L}$. Degree of confounding bias related to smoking, ethnic group and SES in estimates of the association between occupation and cancer. J Occup Med 1988;30:617-25.

49 Asp A. Confounding by variable smoking habits in different occupational groups. Scand J Work Environ Health 1982; 10:325-6.

50 Blair A, Hoar S, Walrath J. Comparison of crude and smoking adjusted SMRs. J Occup Med 1985;27:881-4.

Accepted 11 June 1990

\section{Destruction of manuscripts}

From 1 July 1985 articles submitted for publication will not be returned. Authors whose papers are rejected will be advised of the decision and the manuscripts will be kept under security for three months to deal with any inquiries and then destroyed. 